\title{
Når pasienten vekker det verste i deg
}

Noen pasienter er så krevende at de vekker følelser av frustrasjon, håpløshet og sinne hos sykepleiere. Hvordan kan de få bedre holdninger til disse pasientene?

\section{Forfattere}

Kathrine Benedikte Larsen

Psykiatrisk sykepleier

\section{Nøkkelord}

Psykiatrisk lidelse Selvmord Selvskading

Sykepleien 2017 105(1)(62-66)

DOI: https://doi.org/10.4220/Sykepleiens.2017.59760

\section{HOVEDBUDSKAP}

Krenkende og nedlatende holdninger overfor pasienter med lidelsen emosjonell ustabil personlighetsforstyrrelse (UPF) finnes i stor grad i akuttpsykiatrisk avdeling. Kunnskap om kronisk suicidalitet, endring av avdelingskultur samt bearbeiding av sinne og motoverføringer i veiledning kan bidra til å endre disse holdningene og lindre pasientens lidelse. 
«Ja, nå er hun her igjen! Ikke denne gangen heller har hun klart å fullføre selvmordet (himler med øynene). Det er bare tomme trusler, og skrik om oppmerksomhet. Vi må få henne utskrevet fortest mulig, her har hun i hvert fall ingenting å gjøre, selv om vi sikkert snart ser henne igjen. Å nei! Drama, selvskading og oppmerksomhet på høyt nivå. Hvorfor kommer hun til oss nå igjen? Nå må det da være noen andre sin tur! Når skal hun ta ansvar for seg selv? Jeg vil i hvert fall ikke være primærkontakt denne gangen!»

Slike tanker er ikke uvanlige hos dem som arbeider med pasienter med emosjonell ustabil personlighetsforstyrrelse (UPF). Karin Dyhr har selv vært «svingdørspasient» gjennom en årrekke. Hun har merket personalets holdninger. I sin bok beskriver hun det som ufattelig flaut å være «en sånn en» som manipulerer og bare er ute etter oppmerksomhet. Når hun gang på gang hørte at «nå må du ta deg sammen og oppføre deg som et voksent menneske», var skamfølelsen sterk, og hun følte også ofte sinne (1).

\section{Sårbar pasientgruppe}

Pasienter med UPF er en svært sårbar pasientgruppe med et høyt lidelsestrykk. I Norge har cirka 1,2 prosent av befolkningen UPF (2). Det er utbredt og vel dokumentert at mange som arbeider med UPFpasienter, har negative holdninger overfor denne pasientgruppen (3-13). Slike holdninger påvirker tydelig omsorgen som blir gitt, i negativ retning (13). 
Erfaringsmessig kan pasienter med UPF ofte vekke følelser av frustrasjon, håpløshet, sinne og avmektighet hos sykepleiere på akuttpsykiatrisk avdeling. Grunntonen i arbeidsmiljøet kan til tider være belærende og fordomsfull. Pasientene oppfattes som oppmerksomhetssyke og infantile, noe som har gjort at jeg er blitt mer og mer oppmerksom på at sykepleierne til tider har svært negative holdninger overfor denne pasientgruppen.

Min oppfatning er også at sykepleiere ofte kan glemme den psykiske smerten denne sårbare pasientgruppen lever med. Derfor ønsket jeg å finne ut av om noe kan gjøres for å endre sykepleiernes holdninger til det bedre, og i så fall om bedre holdninger kan gi en bedre forståelse for pasientene, som bidrar til å lindre lidelsen deres. I artikkelen har jeg til hensikt å svare på spørsmålet «Hvorfor har sykepleiere på akuttpsykiatrisk avdeling negative holdninger ovenfor pasienter med emosjonell ustabil personlighetsforstyrrelse, og hvordan kan bedre holdninger bidra til å lindre lidelsen hos disse pasientene?». Jeg har gjort en litteraturstudie der jeg har brukt materiale som allerede er dokumentert og publisert i bøker og artikler. I tillegg har jeg implementert egne erfaringer.

\section{Definisjon av UPF}

Pasienter med UPF er «stabile i sin ustabilitet» (14). Deres psykiske smerte gir seg utslag i usikkerhet, lav selvfølelse, kontinuerlig indre tomhet og frykt for å bli forlatt, noe som kan utløse blant annet promiskuøs atferd og rusmisbruk (5). De pendler mellom ekstremvarianter som idealisering eller sterk nedvurdering, og det finnes ikke gråsoner (10). Sinne er den mest utbredte affekten hos pasientene, enten den er passiv eller utagerende (14). I bakgrunnen lurer en impulsivitet som henger sammen med redsel og frustrasjon (10). 
Redselen for å bli avvist kan bli så altoppslukende at personen kan gjøre hva som helst for å slippe unna den. Samtidig kan pasienten være både klamrende og distanserende (14) og må gå til ytterligheter av handlinger og følelser for å bli sett og få omgivelsene til å «våkne» (6). I kjølvannet følger skyldfølelse, angst og hjelpeløshet (14). Felles for mange er at de har kjørt seg fast i en selvdestruktiv sirkel, ute av stand til å se det selv. En annen fellesnevner er at problemene stammer fra noe utenfor pasientens kontroll - og tilsvarende at løsningen heller ikke er innenfor deres rekkevidde (15).

Kronisk suicidalitet er et vanlig kjennetegn ved UPF og betegner «et mønster av suicidalitet som er kontinuerlig, repetitivt og fyller en mellommenneskelig funksjon» (16). Suicidaliteten blir kronisk idet pasientene forsøker å løse problemer via selvmordsatferd. Ofte kan tilfeldigheter eller uflaks avgjøre om de overlever eller dør (17). Pasienter med UPF er ambivalente til liv og død og forsøker helst å begå selvmord i nærvær av andre som kan redde dem $(9,16)$.

Motoverføring er et annet begrep som ofte brukes i tilknytning til UPF-pasienter. Begrepet betegner personalets følelser og fantasier som har å gjøre med behandlingssituasjonen, og det henger sammen med pasientens væremåte $(14,18)$. Ofte kan man snakke om motoverføringer idet pasientens væremåte «smitter over på» sykepleieren. Dette kan føre til at sykepleieren kan si eller gjøre ting som ikke gagner behandlingssituasjonen.

\section{Ansattes holdninger}


I dette avsnittet drøfter jeg sykepleiernes holdninger til pasienter med emosjonell ustabil

personlighetsforstyrrelse, og hvorfor holdningene er slik. Litteraturen gir mange eksempler på negative og krenkende holdninger til lidelsen. Uttalelser som «å trippe rundt på tå hev» og at «man må være varsom med hva man sier og gjør for at vulkanen ikke skal få utbrudd», kan beskrive sykepleiernes opplevelse i samhandling med disse pasientene (10).

De mange negative karaktertrekkene til pasienter med UPF kan gi god grunn til forhåndsdømming, antiterapeutiske holdninger og motoverføringstendenser $(5,14)$. UPF-pasienter med sitt indre kaos har ofte en tendens til å irritere personalet, med det resultatet at de ikke alltid blir behandlet profesjonelt (19). Det kan gå så langt at sykepleierne blir ofre for motoverføringer og utvikler fiendtlighet og sarkasme, som igjen kan skape negative holdninger (19). Dette kan føre til en utmattingseffekt hvor personalet kan bli distansert og kynisk og miste empatien $(9,10,20)$.

I forskningen finner man holdepunkter for at UPFpasientenes suicidale tendens, utagerende atferd $(3,8)$, manipulasjon og krav om oppmerksomhet og mangel på å ta ansvar for egne handlinger (12) gir opphav til dårlige holdninger. Også travle sykehusavdelinger, inkompetanse hos personalet samt oppfattelsen av at pasienten har større kontroll over sin negative atferd enn vedkommende gir uttrykk for, påvirker negativt (8). Videre gir det grobunn for negative holdninger at pasientene er mindre syke enn andre pasienter (11), og at pasientene ikke hører hjemme i avdelingen (8). 
På bakgrunn av disse momentene har jeg valgt tre emner som danner grunnlaget for artikkelens diskusjon: kunnskap om kronisk suicidalitet, endring av avdelingskultur og bearbeiding av sinne og motoverføringer i veiledning. Videre diskuterer jeg hva som kan bidra til at sykepleiere på akuttpsykiatrisk avdeling kan få bedre holdninger til pasienter med emosjonell ustabil personlighetsforstyrrelse.

\section{Bedre kunnskapen}

Kunnskap, utdanning og profesjonell trygghet i rollen som sykepleier kan gi bedre holdninger til pasienter med UPF (8). Undersøkelser viser at psykiatriske sykepleiere har behov for et «forståelsesrammeverk» overfor pasienter med UPF. Undervisning og kunnskap kan skape denne forståelsesrammen. Når sykepleierne har et slikt rammeverk, kan holdningene bli mer positive (12). Dette rammeverket kan bestå av kunnskap om pasientenes ofte traumatiske bakgrunn, men også av miljøterapeutiske metoder som å skape allianse (12).

I en annen studie om samhandling i arbeidet med UPFpasienter ble det undersøkt om personalet kunne endre sine negative holdninger ved å delta på et undervisningsprogram om UPF. Etter endt program viste det seg at de som deltok, hadde fått større innsikt og mer empati, og derav bedre holdninger. Personalet ønsket i mindre grad å unngå disse pasientene.

Følelsen av mestring og økt kompetanse i samarbeid med pasientene var også resultater av mer kunnskap og undervisning (11).

\section{Endre avdelingskultur}


Ved å endre en negativ avdelingskultur kan holdninger forbedres (8). Høyt arbeidstempo og -press fremheves som noe av opphavet til negativiteten. Stroud og Parsons hevder at psykiatriske sykepleiere ofte er medisinsk orienterte, noe som usynliggjør de menneskelige aspektene (12). Til sammen kan arbeidspress og økt medisinsk orientering legge press på samhandlingen mellom kollegaer, noe som i sin tur kan gå ut over pasientene. En studie i Israel viste at sykepleiere hadde minst empati for UPF-pasienter sammenliknet med psykologer og psykiatere (3). En grunn til dette kunne være at sykepleierne er i «frontlinjen»; de er rundt pasientene hele døgnet, noe som kan føre til frustrasjon og utbrenthet.

\section{Veilede personalet}

Generelt er holdningene overfor pasienter med UPF ofte negative, og pasientene fremmer irritasjon og sinne hos personalet $(11,19)$. Dette danner grunnlag for motoverføringer. Derfor er det svært viktig å veilede personalet som jobber tett på pasienter med UPF, for at de skal få luftet sine følelser, enten de handler om for mye engstelse eller for mye forsvar overfor pasienten (8, 9, 13, 17,). En studie sammenliknet terapeuters følelsesmessige kontekst da pasienter med UPF ble behandlet, kontra pasienter med alvorlig depresjon (4). Det ble funnet at følelsesmessig stress var klart forhøyet da førstnevnte gruppe ble behandlet. De fant også at arbeid med pasienter med alvorlig depresjon ble oppfattet som en mer takknemlig oppgave, der sykepleierne også viste mer empati. Personalet som jobbet med UPFpasientene, hadde behov for mer støttende veiledning grunnet en oppfatning av at UPF-pasientene var mer fiendtlige, narsissistiske, engstelige, seksualiserende, sensitive for avvisning og vanskelige å jobbe med enn gruppen med alvorlig depresjon (4).

\section{Kronisk suicidale}


Her presenterer jeg hvordan kunnskap om UPF og kronisk suicidalitet kan gi bedre holdninger og dermed lindre lidelsen til UPF-pasienter. Erfaringsmessig er det en følelsesmessig påkjenning å ta seg av pasienter med UPF samt å skulle forholde seg til en potensiell selvmordsrisiko. Pasientenes selvmordstrusler kan få sykepleierne til å føle seg som «emosjonelle gisler» (19). En seiglivet myte er at pasientene skader seg for å få oppmerksomhet, eller for å straffe og manipulere mennesker rundt seg.

Sykepleiere gjør seg ofte til talsmenn for slike oppfatninger eller enkle forståelsesmodeller (10). Fakta om selvmordstall sier dog noe annet, siden 3-7 prosent av pasientene med UPF ender opp med å ta livet sitt (9). Det finnes imidlertid mennesker som gir uttrykk for at de vil lide, eller som oppsøker lidelse, men som ikke er i stand til å formidle denne lidelsen. Dersom disse pasientene blir møtt med mistro eller som om de simulerer, øker lidelsen deres ytterligere (21).

Nedverdigende og krenkende holdninger som følge av selvmordsforsøk forsterker pasientens følelse av verdiløshet (22). Når grensene testes, reagerer sykepleierne ofte både med angst, frykt og sinne, noe som er gode og naturlige måter å reagere på. Men når disse følelsene får blomstre og forvrenges til skyld, behov for å skylde på andre, fleip, negative holdninger eller likegyldighet, kan det bli en farlig utvikling (19).

\section{Årsaker til selvskading}


Ifølge forskningen er ikke den kroniske suicidaliteten alltid et oppmerksomhetsbehov, men en følelse av at «alt gjør så vondt» $(6,10)$. Dersom sykepleierne tilegnet seg kunnskap fra et brukerperspektiv, kunne dette kanskje bidra til bedre forståelse, som igjen kunne bidra til å lindre lidelsen. Pasientene formidler at de noen ganger har bruk for den oppmerksomheten selvskading kan gi dem, eller at de ønsker å straffe andre. Men de selvskader også for å straffe seg selv, avlede indre smerte og selvmordstanker eller for å flykte (10). Fordi følelsene ofte er styrende hos UPFpasienter, kan de utløse impulsive handlinger som å skade seg selv (6). Når håpløsheten veller frem, forsøker en med UPF-lidelse jevnlig å skjære eller blø ut de overgrepene som ikke lar seg fjerne på annen måte. Selv om selvskading gir en kortvarig lindring, kan den også gi tilstrekkelig lindring mot selvmordstanker (1).

Pasientenes kroniske suicidalitet fører ofte til at andre mennesker bryr seg om dem. Derfor er det viktig for sykepleiere å vite at pasientens redsel for å bli forlatt kan gjøre at de ikke vil gi opp denne atferden (9). De som ikke forstår verdien pasienten har med å forbli suicidal, legger for mye vekt på å eliminere selve suicidaliteten. Pasientene kan derfor føle seg svært misforståtte når de møter helsepersonell som vil fjerne ethvert spor av dette (9). Konstante overveielser om hvorvidt man skal begå selvmord eller ikke kan faktisk oppfylle verdifulle psykologiske funksjoner for pasienten: «Suicidalitet kan faktisk være avgjørende for pasientens søken etter en grad av verdighet, autonomi og forbundethet som kunne vært verdt å leve for» (19, s. 137). I lys av dette bør sykepleierne forstå at ambivalensen til liv eller død må tas alvorlig og bør reflekteres over (17). Pasienten trenger å føle seg sett og hørt, samt at noen validerer vedkommendes følelser (9).

\section{Utvis empati}


Dersom krenkelse og vanære har blitt en integrert del av en person, er det ikke lett å bli glad i seg selv. Empatisk lytting kan bidra til å forstå pasientens selvforakt, selvbilde og selvaktelse i forbindelse med kronisk suicidalitet (23). Sykepleiere bør kunne sette seg inn i pasientens situasjon for å forstå disse aspektene og for å kunne lindre pasientens psykiske smerte (9). Det å bli møtt som likeverdig og ikke med en ovenfra og ned-holdning er avgjørende (8). I sin rolle kan UPF-pasientene spille tøffe og arrogante. Bak fasaden kan det ligge et ønske om bekreftelse. Det er lett å tolke oppførselen som utspill og manipulasjon, men om man ikke ser bak denne atferden, kan det lede til gjensidig mangel på respekt (10).

Idet noe blir kronisk, blir det ofte håpløst. Uttrykket «kronisk suicidalitet» kan derfor også bidra til å skape fordommer. I den senere tiden er kronisk suicidalitet blitt en vanlig innleggelsesårsak for UPF-pasienter i akuttpsykiatrisk avdeling. Samtidig legger Nasjonale retningslinjer for selvmordsforebygging (24) føringer for at mennesker med kronisk suicidalitet ikke bør behandles i akuttpsykiatrien.

\section{Endre avdelingskulturen}

Videre diskuterer jeg hvordan en endring av avdelingskulturen kan bidra til bedre holdninger og dermed lindre lidelsen til UPF-pasienter.

Avdelingskulturen har mye å si for hvordan holdninger formes og vedlikeholdes (12). På akuttpsykiatrisk avdeling er det nedfelt i reglene at de ansatte ikke skal gi personlige opplysninger om eget liv eller bakgrunn, og det skal være et klart skille mellom pasient og personale. Objektiviteten er viktig i samhandling med UPF-pasienter, nettopp for ikke å komme for nær (15).

Det hender likevel at noen overtolker dette med objektivitet og nærmest blir umenneskelige i behandlingen av pasientene. Det kan gi en farlig utvikling. De glemmer mennesket bak lidelsen (15). 
Fastlåste tankemønstre gjør helsepersonell mindre profesjonelle, og noen ganger kyniske. En kynisk holdning kan bidra til å øke pasientens lidelse, hevder Perseius. Enkle midler kan forandre dette, og det bør håndteres som et arbeidsmiljørelatert problem der hovedansvaret ligger hos avdelingslederen. Lav toleranse for kynisme kan hindre en ukultur (10). Utfordringen er at det er vanskelig å si hvor grensen skal gå - for når blir fleip til sarkasme? Forskning fra et pasientperspektiv kan også her bidra til økt innsikt og etisk refleksjon. I en studie rapporterte UPFpasienter om traumatiske opphold i akuttpsykiatriske avdelinger hvor de merket de negative holdningene på kroppen (8). Ikke sjelden følte pasientene seg som objekter. Travelhet i avdelingen kunne være en årsak (8). Effektivisering gjør at helsepersonell må anvende manualer og skjemaer fremfor å kunne fokusere på selve samtalen. Martinsen peker på en dehumaniserende praksis som følge av dette (25).

\section{Sårbare sykepleiere}

Man kan snakke om en distansekultur versus en nærhetskultur på akuttpsykiatriske avdelinger. På den ene siden kan sykepleiere bidra til at avdelingen har en smidig relasjon og nærhet til pasientene, mens de på den andre siden kan være ufleksible og styrt av regler med overordnet fokus på sikkerhet (10). Sistnevnte minner om dehumanisering, der vi glemmer mennesket. Vi risikerer å bli ekstreme og kontraproduktive. Med økt bevissthet, kunnskap, refleksjon og veiledning kan sykepleierne bli mer bevisste på hvordan de fremstår (10). 
Det finnes pasienter som ikke så lett vekker medfølelse hos helsepersonell, og som blir anklaget for selv å være skyld i egen tilstand. Martinsen hevder at slike holdninger ikke er politisk korrekte, men at man som profesjonell bør forsøke å endre etiske retningslinjer slik at visse pasientgrupper ikke blir stigmatisert. Hun hevder videre at sykepleieren må evne å være sårbar for å kunne leve seg inn i pasientens lidelse. Når sykepleieren ikke er sårbar, kan hun eller han bli kynisk og krenke pasienten (26).

\section{Bearbeide sinne}

Til sist diskuterer jeg hvordan bearbeiding av sinne og motoverføringer i veiledning kan bedre holdninger og dermed lindre lidelsen til UPF-pasienter. I arbeid med UPF-pasienter må vi sykepleiere tørre å kjenne på og snakke om de vanskelige følelsene disse pasientene vekker i oss, altså motoverføringsreaksjoner (7). Gjennom motoverføringer som blir hatefulle, straffer man ubevisst pasienten (20). En annen risiko ved motoverføringer er å distansere seg, bli sint og ta igjen (13). Noen mister dessuten empatien (20). Ofte benekter og underkjenner vi reaksjonene våre. Om vi ikke lytter til oss selv, kan det føre til utbrenthet, uprofesjonell atferd og terapihindring (14). 
Personalet kan bli provosert, nærmest fiendtlig, og skylder på pasienten når behandlingen ikke fører frem (1). Samtidig kan sykepleieren svinge fra å vise overdreven omsorg og vennlighet til å være fordømmende, kort og negativ (6). Opptrer vi sykepleiere da som pasientene selv? Når en sykepleier er blitt «offer» for motoverføringer, kan det hindre vedkommende i å se pasienten som lidende, desperat og med stort behandlingsbehov (9). Pasienten kan også overføre aggressive følelser til oss sykepleiere, slik at vi faktisk blir aggressive. Derfor må sykepleierne kunne styre sitt sinne om man har håp om at pasienten skal gjøre det samme (9). På samme måte som UPFpasienten kan lære å regulere sine følelser gjennom traumemodellens toleransevindu, kan kanskje sykepleiere få opplæring i samme metode for å håndtere sine følelser knyttet til for eksempel sinne. Toleransevinduet er et forholdsvis enkelt verktøy hvor man ofte med enkle grep kan lære å «hente seg inn», slik at man verken blir overaktivert (angstfylt, sint) eller underaktivert (apatisk, uempatisk) (23).

\section{Stor skamfølelse}

Det er lite hensiktsmessig å påføre pasientene mer skam og smerte enn nødvendig. Er det noe mange av disse har opplevd, er det nettopp skam og smerte. Derfor mener Nilson og Silfving at UPF-pasientene ikke bare er lunefulle og håpløse, men mennesker med enestående egenskaper og mye kreativitet - noe vi ikke må glemme. De mangler både språk og stemme for å formidle sine tanker og følelser (14). Det er derfor et påtrengende behov at helsepersonellet ser pasientens eksistensielle livsverden og at de ikke betrakter pasienten som en diagnose (27). 
Behandlingens kompleksitet henger sammen med terapeutens respons, ikke bare med pasientens atferd (4). Dersom man ofte opplever sinne overfor pasienter med UPF, bør man prøve å identifisere hva det sårbare i situasjonen er, fordi pasienten gjerne rører ved noe som er følsomt og sårbart. Man bør forsøke å distansere seg fra tanker som «hun burde ikke oppføre seg slik». Ved å se pasientene fra deres side, kan man oppdage at den til tider provoserende atferden er et utslag av bristende ferdigheter, og at de ofte gjør så godt de kan (10).

\section{Aksepter eget sinne}

Samtidig kan man trene seg på å akseptere sinne ved å observere det. De som arbeider med disse pasientene, må tåle å leve med større frustrasjoner og provokasjoner enn normalt. Det er lov å bli opprørt, og hvis man blir det, kan man reparere skaden i ettertid. Dermed viser man pasienten at det er lov å bli opprørt og at slik oppførsel også forekommer i det virkelige liv (6). Det å avreagere på vaktrommet er helt sentralt, og ikke sjelden kan både bisarr humor og tabubelagte utsagn hjelpe personalet til å håndtere pasienter med UPF (7).

Veiledning handler mye om å justere egne reaksjoner, reflektere over hvordan man opptrer og arbeide med hvordan man kan bruke seg selv i møte med pasienten, noe som også kan være en viktig kilde til fagutvikling. For å forstå disse pasientene er det derfor viktig å få frem helhetsperspektivet (17). Om man i veiledning lar hver og en av de ansatte som har med pasienten å gjøre, fremstille sitt bilde av vedkommende, kan det bidra til å danne et slikt perspektiv (14).

Veiledning anses også som viktig for å hindre utbrenthet (23). Det kan oppstå et dilemma i dagens psykiatri når vi tar på oss for mye (17). Avslutningsvis bør vi hele tiden være selvkritiske når det gjelder etisk bevissthet og bringe den frem i lyset (10).

LES OGSÅ: Få pasienten ut av offerrollen 


\section{Referanser}

1. Dyhr K. Bag om borderline. København: Nyt Nordisk Forlag, Arnold Busck. 2010.

2. Torgersen S. Epidemiology. I: Oldham JM, Skodol AE, Bender DS (red.). The American psychiatric publishing textbook of personality disorders. Washington DC: American Psychiatric Publishing. 2005.

3. Bodner E, Cohen-Fridel S, Iancu I. Staff attitudes toward patients with borderline personality disorder. Comprehensive Psychiatry 2011;52:548-55.

4. Bourke ME, Hons BA, Grenyer BFS. Therapists' accounts of psychotherapy process associated with treating patients with borderline personality disorder. Journal of Personality Disorders 2013;27(6):735-45.

5. Hummelvoll JK. Helt - ikke stykkevis og delt. Psykiatrisk sykepleie og psykisk helse. Oslo: Gyldendal Akademisk. 1982.

6. Kåver A, Nilsonne Å. Dialektisk atferdsterapi ved emosjonell ustabil personlighetsforstyrrelse. Oslo: Gyldendal Norsk Forlag. 2009.

7. Larsen K. «Bare gå og heng deg, din jævla dritt!!». Motoverføring og suicidalitet. Suicidologi 2011;16(1):18-24.

8. McHale J, Felton A. Self-harm: What's the problem? A literature review of the factors affecting attitudes towards self-harm. Journal of Psychiatric and Mental Health Nursing, 2010;17:732-40.

9. Paris J. Half in love with death. Managing the Chronically Suicidal Patient. Lawrence Erlbaum Associates Inc. Library of Congress Cataloging-inPublication Data. 2007. 
10. Perseius KI. Att temja en vulkan. Om

emotionell instabilitet och självskadebeteende. Lund:

Studentlitteratur. 2012.

11. Shanks C, Pfohl B, Blum N, Black D. Can negative attitudes toward patients with borderline personality disorder be changed? The effect of attending a STEPPS workshop. Journal of Personality Disorders 2011;25(6):806-12.

12. Stroud J, Parsons R. Working with borderline personality disorder: A small-scale qualitative investigation into community psychiatric nurses' constructs of borderline personality disorder. Personality and Mental Health 2013;7:242-53.

13. Winship G. Research in brief. Attitudes and perceptions of mental health nurses towards borderline personality disorder clients in acute mental health settings: a review of the literature. Journal of Psychiatric and Mental Health Nursing 2010;17:65762.

14. Nilson G, Silfving T. Farlige relationer - om borderline. København: Nordisk Forlag. 2002.

15. Masterson JF. Det truede selv. Borderline og narcissisme - personlighetsforstyrrelser i det moderne samfund. København: Hans Reitzels Forlag. 1990.

16. Paris J. Kronisk suicidalitet ved ustabil personlighetsforstyrrelse. Hvorfor det er behov for særskilte tilnærminger i behandlingen. Suicidologi 2010;1:3-7.

17. Vråle GB. Møte med det selvmordstruede mennesket. Oslo: Gyldendal Akademisk. 2000.

18. Karterud S, Wilberg T, Urnes Ø.

Personlighetspsykiatri. Oslo: Gyldendal Norsk Forlag. 2011. 
19. Gabbard GO, Wilkinson SM. Borderline

behandling og modoverføring. København: Hans

Reitzels Forlag AS. 2002.

20. Wilhelmsen I. Det er ikke mer synd på deg enn andre. - En bok om ansvar og frigjøring. Stavanger:

Hertervig Forlag, Stiftelsen Psykiatris Opplysning. 2012.

21. Erikson K. Det lidende menneske. Otta:

TANO. 1995.

22. Vatne M, Nåden D. Patients' experiences in the aftermath of suicidal crisis. Nurs Ethics 2014;21(2):163-75.

23. Anstorp T, Benum K, Jakobsen M.

Dissosiasjon og relasjonstraumer. Integrering av det splittede jeg. Oslo: Universitetsforlaget. 2012.

24. Sosial- og helsedirektoratet. Nasjonale retningslinjer for forebygging av selvmord i psykisk helsevern. 2008. Tilgjengelig fra:

https://helsedirektoratet.no/lists/publikasjoner/attachments/3/nasjonal-... (Nedlastet 15.12.2016).

25. Martinsen K. Fra Marx til Løgstrup. Om etikk og sanselighed i sygeplejen. Oslo: TANO. 1993.

26. Martinsen K. Løgstrup og sykepleien. Oslo: Akribe. 2012. 